\title{
Geochemical Implication of Chemical Composition of Mineral Water (Bottled Water) Produced Near Mt. Baekdu (Changbai), Northeast China
}

\author{
Seung-Gu Lee ${ }^{1, *(\mathbb{D}}$, Dong-Chan Koh ${ }^{2} \mathbb{D}$, Kyoochul Ha ${ }^{2}$, Kyung-Seok Ko ${ }^{2} \mathbb{D}$, Youn Soo Lee ${ }^{3}$, Youn-Young Jung ${ }^{4}$, \\ Zhihui Cheng ${ }^{5}$ and Shuang-Shuang Chen ${ }^{6}$
}

check for

updates

Citation: Lee, S.-G.; Koh, D.-C.; Ha, K.; Ko, K.-S.; Lee, Y.S.; Jung, Y.-Y.; Cheng, Z.; Chen, S.-S. Geochemical Implication of Chemical Composition of Mineral Water (Bottled Water) Produced Near Mt. Baekdu (Changbai), Northeast China. Water 2021, 13, 2191. https://doi.org/ $10.3390 / w 13162191$

Academic Editor: Brunella Raco

Received: 5 July 2021

Accepted: 9 August 2021

Published: 11 August 2021

Publisher's Note: MDPI stays neutral with regard to jurisdictional claims in published maps and institutional affiliations.

Copyright: (c) 2021 by the authors. Licensee MDPI, Basel, Switzerland. This article is an open access article distributed under the terms and conditions of the Creative Commons Attribution (CC BY) license (https:/ / creativecommons.org/licenses/by/ $4.0 /)$.
1 Geology Division, Korea Institute of Geoscience and Mineral Resources, 124 Gwahak-ro, Yuseong-gu, Daejeon 34132, Korea

2 Geologic Environment Research Division, Korea Institute of Geoscience and Mineral Resources, 124 Gwahak-ro, Yuseong-gu, Daejeon 34132, Korea; chankoh@kigam.re.kr (D.-C.K.); hasife@kigam.re.kr (K.H.); kyungsok@kigam.re.kr (K.-S.K.)

3 Division of Environmental Science Engineering, POSTECH, 77 Cheongam-ro, Nam-gu, Pohang 37673, Gyeongbuk, Korea; younsoo@postech.ac.kr

4 Division of Environmental Science Engineering, Korea Basic Science Institute, Cheongju 28119, Chungbuk, Korea; jyy0211@kbsi.re.kr

5 School of Geographical Sciences, Lingnan Normal University, Zhanjiang 524048, China; chengzhihui0320@126.com

6 Guangdong Provincial Key Laboratory of Geodynamics and Geohazards, School of Earth Sciences and Engineering, Sun Yat-sen University, Guangzhou 510275, China; chenshsh29@mail.sysu.edu.cn

* Correspondence: sgl@kigam.re.kr; Tel.: +82-42-868-3376; Fax: +82-42-868-3413

\begin{abstract}
Two kinds of bottled mineral water from wells located in the northern (Baeksansu, BSS) and southern (Baekdusansu, BDS) areas near Mt. Baekdu (Changbai) were collected in order to monitor the chemical compositions of the groundwater near a potential volcanic area. The bottled water was produced between August 2014 and June 2017, and corresponds to the $\mathrm{Na}-\mathrm{HCO}_{3}$ water type. The trend in variation of each chemical component between the two bottled waters was different. The BDS bottled water from the southern area of Mt. Baekdu showed a dramatic change in chemical composition during the study period, whereas the BSS bottled water from the northern area did not show any significant change in chemical composition. In particular, the BDS bottled water showed either systematic increases or decreases of chemical components relative to the $\mathrm{Cl}$ concentrations. However, the BSS bottled water did not show such trends. It was confirmed that the chemical composition in the groundwater was constant, even though the monitoring period lasted for about two years. Our data indicate that it may be possible to use the chemical composition of the bottle water produced from the groundwater in the volcanic area as a proxy for monitoring the geochemical environmental change of the groundwater aquifer.
\end{abstract}

Keywords: bottled water; chemical composition; monitoring; proxy; tectonic activity

\section{Introduction}

Mt. Baekdu (Changbai) volcano, which is located at the border between China and the Korean Peninsula, is one of many potentially eruptive volcanos in the world. Recently, many researchers expected that Mt. Baekdu might erupt again in the near future [1-4]. Notably, Shangguan et al. [5] and Hahm et al. [6] have tried to exploit contemporary geothermal activity associated with recent volcanism at Mt. Baekdu using gas components, such as $\mathrm{He}$ and $\mathrm{CO}_{2}$, from the geothermal volatiles. These authors mentioned that a stable reservoir of geothermal water and deep-seated gases may exist under the Mt. Baekdu geothermal area. In addition, Han and Huh [7] reported that, using geothermometric calculations and $\delta \mathrm{D}-\delta^{18} \mathrm{O}$ data, the hot spring waters of $\mathrm{Mt}$. Baekdu emerge at the surface before attaining equilibrium with their host rock, even though meteoric water infiltrates the 
geothermal field in the Mt. Baekdu area. Recently, Yan et al. [8-10] reported that chemical compositions of the hot spring and mineral (spring) water in Mt. Baekdu were produced from water-rock interaction through the deep and long water cycle of the thermal water. However, there were no reports of systematic observations concerning the hydrogeochemistry of the groundwater in the Mt. Baekdu area. This is due to the fact that this area is a border area between China and North Korea and is a nature reserve, and so it is very difficult to systematicallly collect groundater and hot spring water around Mt. Baekdu.

Since 2009, a large amount of research results related to the geochemical characteristics of bottled water have been reported [11-26]. The chemical composition of bottled water is a result of water-rock interactions in the bedrock aquifer (such as groundwater or surface water) $[27,28]$, and therefore can provide us with information about the main hydrogeochemical processes and influences controlling the chemical content of the bottled water. Particularly, since bottled water produced from natural spring or groundwater wells have relatively constant chemical compositions, their chemical component monitoring may provide important information for tracing the variation of geochemical factors in groundwater reservoirs. For example, based on the survey of bottled waters produced near the epicenter of the 17 January 1995 Kobe Earthquake, Tsunogai and Wakita [29,30] reported that the chemical contents of the bottled water showed anomalous changes before and after the earthquake. This means that the chemical composition of mineral water might be altered due to crustal activity such as earthquakes or volcanic activity. It also indicates the possibility that monitoring of the chemical composition of mineral water (such as the bottled water which was produced from groundwater in accessible areas) could be used to detect chemical changes in the groundwater caused by geological fluctuations in the crust.

Therefore, in this study, we monitored the hydrogeochemical characteristics of the groundwater near the Mt. Baekdu area using bottled waters produced in the surrounding area. We also compared the hydrogeochemical characteristics of the bottle with those of hot spring water and cold spring water in the surrounding area of Mt. Baekdu using our collected waters and the data available in the literature [7]. This was undertaken due to the fact that the hydrogeochemistry of the bottled waters from volcanic areas may have, at least, a twofold importance: (1) they may contribute to the understanding of the role of the aquifers of bottled waters in the recharging of groundwaters, and (2) they provide an opportunity to conduct an assessment of possible volcanic activity near the volcanic area.

The objectives of this study were: (a) to monitor the chemical components of the mineral waters produced near to a volcanic area; (b) to ascertain the geochemical implications of the chemical components in the mineral water; and (c) to find a relatively effective geochemical proxy which can monitor geological activity such as volcanic activity or earthquakes.

\section{Materials and Methods}

\subsection{Materials}

Currently, two bottled waters (i.e., Baeksansu (BSS) and Baekdusansu (BDS)) produced near Mt. Baekdu (see Figure 1 for location) can be obtained relatively easily in the supermarkets of Korea. The BSS is a bottled water produced from artesian groundwater at Eedaobai, Jilin Province, China, at an altitude of $670 \mathrm{~m}, 50 \mathrm{~km}$ from the northern gateway of Mt. Baekdu. The BDS is a groundwater produced by pumping in Changbai Country, Jilin Province, China, at an altitude of $800 \mathrm{~m}, 35 \mathrm{~km}$ from the southern gateway of Mt. Baekdu. These two bottled waters are sold in the Korean market within one to two weeks of production.

Two commercial bottled water samples (BSS and BDS) produced near Mt. Baekdu, China were purchased at a retail mart in Korea, based on the label information regarding the production date on the bottle. We collected a total of 75 bottled waters of the two commercial mineral water samples with different dates ranging from August 2014 to June 2017. Of them, sample BSS140801 was purchased at the Eedaobai (Jilin Province, China) when we visited there on August, 2014, which is located area of the product company of 
BSS (Baeksansu). We also collected hot spring and cold spring water samples near the Mt. Baekdu area when we visited this area to collect rock samples in August 2014 (see Table 1). The sample BSS140801 was the motivation for the study of chemical composition change in groundwater around volcanic area using bottled water. The others had been purchased at the supermarket at Korea almost every two or three weeks. All samples including BSS140801 were purchased within one month since they were produced by the product company. This means that all of the measurements for chemical components had been performed within two months since production at the respective sites.

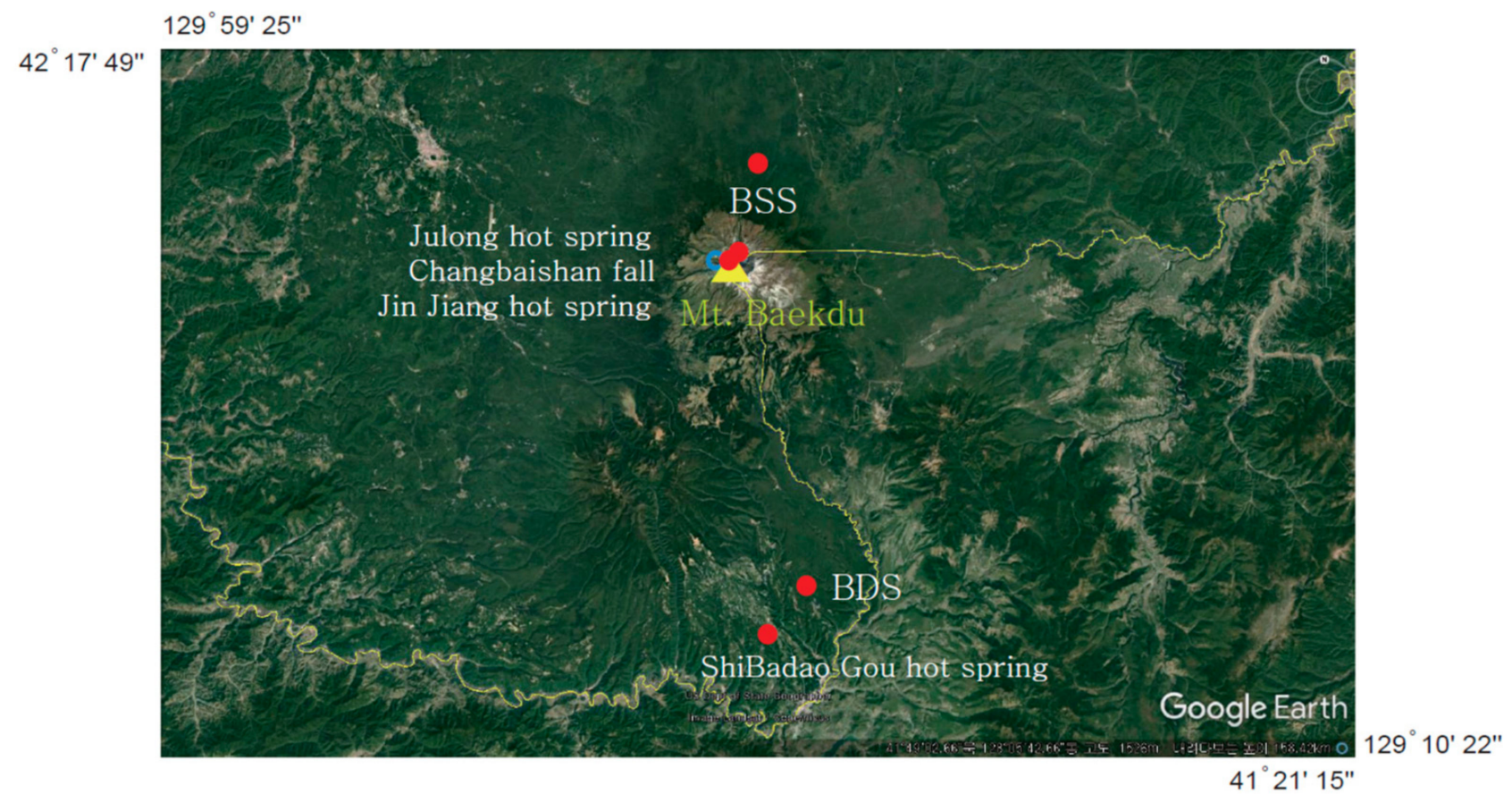

Figure 1. Location map showing the bottled water sample (BSS and BDS) and hot spring waters locations adjacent to Mt. Baekdu (Changbai). Baeksansu, BSS; Baekdusansu, BDS.

Table 1. Basic physical and chemical properties of hot spring water and stream water near to Mt. Baekdu area. EC, Electrical Conductivity; DO, Dissolved Oxygen; Eh, Potential.

\begin{tabular}{ccccccccc}
\hline Name & $\begin{array}{c}\text { Sampling } \\
\text { Date }\end{array}$ & Site Location & $\begin{array}{c}\text { Sample } \\
\text { Classification }\end{array}$ & Temperature $\left({ }^{\circ} \mathbf{C}\right)$ & pH & EC $(\mu S / \mathbf{c m})$ & DO $(\mathbf{m g} / \mathbf{L})$ & Eh $(\mathbf{m V})$ \\
\hline SG17-1 & 17 August 2014 & Shi Bada Guo & Hot spring water & 36.5 & 7.19 & 1738 & 0.57 & -257.3 \\
\hline SG18-1 & 18 August 2014 & Jin Jiang & Hot spring water & 58.4 & 6.45 & 1714 & out of range & -111 \\
\hline SG19-1 & 19 August 2014 & Changbaishan Fall & waterfall water & 7 & 8.34 & 277 & 920 & -23.9 \\
\hline SG19-2 & 19 August 2014 & Changbaishan Julong & Hot spring water & 69.4 & 6.69 & 1695 & out of range & -154 \\
\hline
\end{tabular}

\subsection{Methods}

The analysis for the samples was conducted within one week after purchase, most of which are within one month after being produced in the China, locally.

The collected samples were filtered through $0.2 \mu \mathrm{m}$ Millipore filters before pretreatment for instrumental analysis, and subsequently analyzed for major and minor constituents and hydrogen, oxygen, and $\mathrm{Sr}$ isotope compositions.

Cation concentrations $\left(\mathrm{Ca}^{2+}, \mathrm{Mg}^{2+}, \mathrm{Na}^{+}, \mathrm{K}^{+}, \mathrm{Li}^{+}\right.$, and $\mathrm{Sr}^{2+}$, as well as $\left.\mathrm{SiO}_{2}\right)$ were analyzed using an inductively coupled plasma-optical emission spectrometer (ICP-OES, 8300DV, Perkin Elmer, Waltham, MA, USA) at the Korea Institute of Geoscience and Mineral Resources (KIGAM). The bicarbonate content was determined by titration of $50 \mathrm{~mL}$ of the sample after the bottles had been opened in the laboratory. Then, anion concentrations, such as $\mathrm{Cl}^{-}, \mathrm{SO}_{4}{ }^{2-}$, and $\mathrm{F}^{-}$, were measured using ion chromatography (ICS-3000, Dionex, 
Sunnyvale, CA, USA) at KIGAM. The analytical precision for cations and anions was determined using calculations of the ionic balance error, most of which were generally within $10 \%$.

$\delta^{18} \mathrm{O}$ and $\delta \mathrm{D}$ values were analyzed by wavelength-scanned cavity ring-down spectroscopy (L2120-i, Picarro, Santa Clara, CA, USA) which is one type of isotopic ratio infrared spectroscopy [31] available at KIGAM. Water samples were injected eight times per sample, and the last three or four measurements were used for determination of isotopic compositions to eliminate memory effects. The typical analytical uncertainties are better than $0.1 \%$ and $1 \%$ for $\delta^{18} \mathrm{O}$ and $\delta \mathrm{D}$, respectively [32].

The ${ }^{87} \mathrm{Sr} /{ }^{86} \mathrm{Sr}$ ratio was measured on a TRITON TIMS at KIGAM. The average value for NBS 987 during the analyses was $0.710254 \pm 0.000002\left(2 \sigma_{\mathrm{m}}\right)$ for 30 measurements. The analytical uncertainties were approximately $0.002 \%$ for ${ }^{87} \mathrm{Sr} /{ }^{86} \mathrm{Sr}$. The total procedural blanks during the $\mathrm{Sr}$ isotopic measurements were less than $30 \mathrm{pg}$.

\section{Results}

The chemical parameters such as major ions, stable isotopes, and ${ }^{87} \mathrm{Sr} /{ }^{86} \mathrm{Sr}$ ratios of the hot spring and cold spring waters at the Mt. Baekdu area as well as two bottled waters (BDS and BSS) were summarized in Supplementary Tables S1-S3. The chemical composition of the hot spring and cold spring waters at the Mt. Baekdu area and two bottled waters (BDS and BSS) were summarized in the piper diagram of Figure 2a. The hydrogen and oxygen isotopic data $\left(\delta \mathrm{D}\right.$ and $\left.\delta^{18} \mathrm{O}\right)$ of the two bottled waters were also drawn in Figure 2b.
$\square \quad$ BSS bottled waters
BDS bottled waters
Hot spring water
$\diamond \quad$ Spring water near to hot spring area
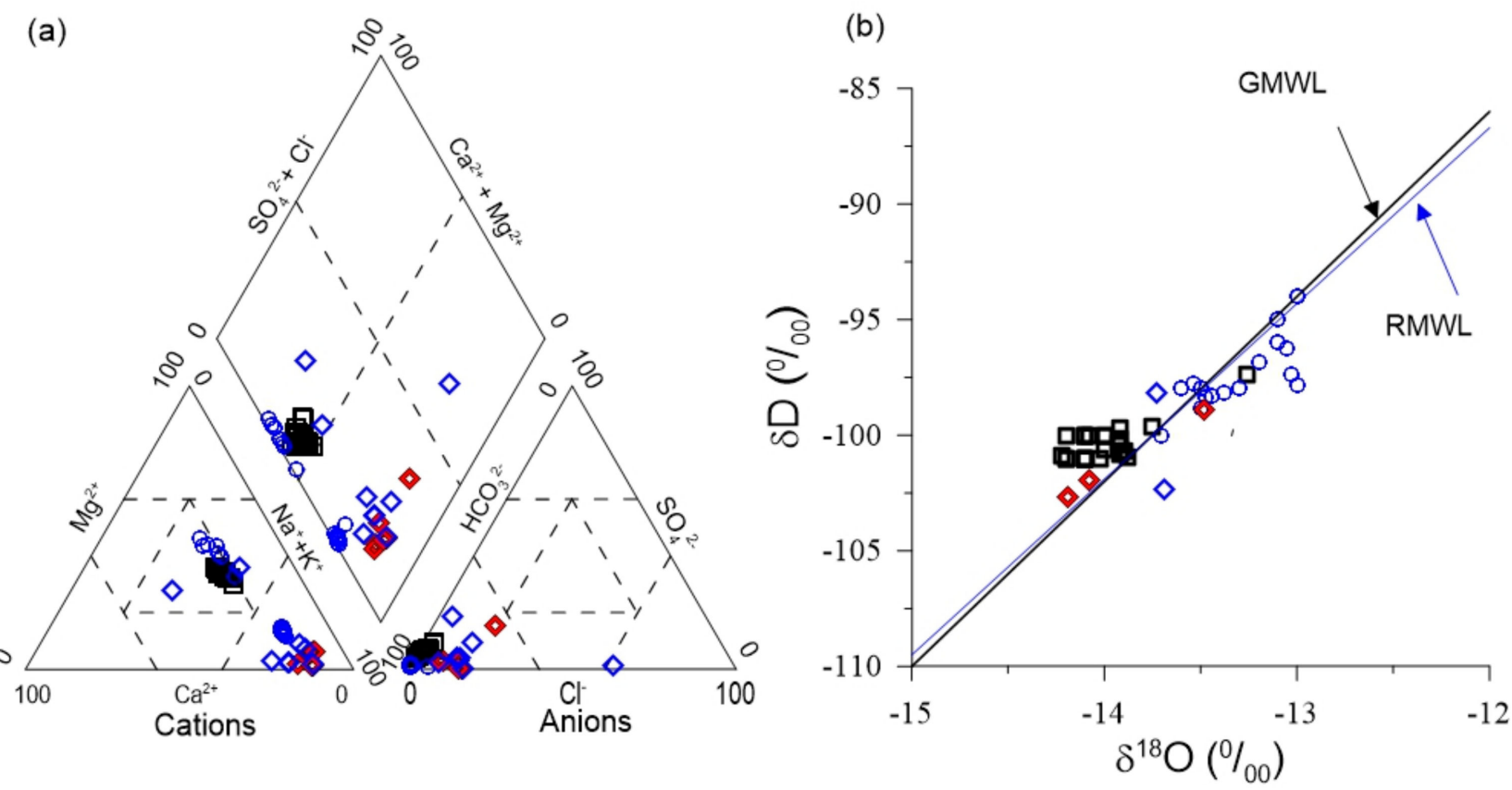

Figure 2. (a) Piper diagram showing compositions of the bottled waters, hot spring waters and stream waters near to the Mt. Baekdu area and $(\mathbf{b})$ isotopic composition $\left(\delta \mathrm{D}\right.$ and $\left.\delta^{18} \mathrm{O}\right)$ of the two bottled waters in this study. GMW and RMWL represent the global meteoric water line [33] and the regional meteoric water line [34], respectively. The data of hot spring water and cold spring waters were used from this study (Table S1) and Han and Huh [7].

Figure 2a shows that most of the samples except one spring water plotted on the far left of the central diamond, which corresponds to the $\mathrm{Na}-\mathrm{Mg}-\mathrm{HCO}_{3}$ type. However, the 
BDS bottled water also shows changes of water type including $\mathrm{Na}-\mathrm{HCO}_{3}, \mathrm{Na}-\mathrm{Mg}-\mathrm{HCO}_{3}$, and $\mathrm{Na}-\mathrm{HCO}_{3}$ during the two-year study period.

$\delta \mathrm{D}$ and $\delta^{18} \mathrm{O}$ values of the BDS bottled waters range from $-94 \%$ to $-100 \%$ and from $-13.0 \%$ to $-13.7 \%$. $\delta \mathrm{D}$ and $\delta^{18} \mathrm{O}$ values of the BSS bottled water range from $-97 \%$ to $-101.9 \%$ and from $-13.3 \%$ to $-14.2 \%$, respectively. In the plot of $\delta \mathrm{D}$ and $\delta^{18} \mathrm{O}$ (Figure 2b), samples from the BDS bottled waters are clustered along the Global Meteoric Water Line (GMWL, $\delta \mathrm{D}=8 \times \delta^{18} \mathrm{O}+10$ ) by Craig [33], whereas the samples of the BSS bottled waters were plotted in a tight cluster on the lower section of GMWL. The Regional Meteoric Water Line (RMWL) by Chen et al. [34] also does not deviate significantly from the GMWL. The relationship between $\delta \mathrm{D}$ and $\delta^{18} \mathrm{O}$ values of the BSS bottled waters seems to suggest that $\delta^{18} \mathrm{O}$ values may be influenced by a $\mathrm{CO}_{2}$ exchange reaction due to water-rock interactions [35]. Slight differences of $\delta \mathrm{D}$ and $\delta^{18} \mathrm{O}$ values between the BDS and BSS bottled waters can be interpreted as corresponding well with the altitude effect [36,37].

The ${ }^{87} \mathrm{Sr} /{ }^{86} \mathrm{Sr}$ ratios for BSS bottled waters were nearly constant $(0.70719 \pm 0.00002$, $\left.2 \sigma_{\mathrm{m}}\right)$ whereas those for BDS bottled waters are divided into two groups; one is $0.70677-0.70686$, while the other is $0.70721-0.70733$ (Tables S2 and S3). The ${ }^{87} \mathrm{Sr} /{ }^{86} \mathrm{Sr}$ ratios from the hot spring waters are 0.70510-0.71589, whereas those from the stream waters are $0.70541-0.709$ (Table S1).

\section{Discussion}

\subsection{Variation of Chemical Composition in the Bottled Waters}

Geochemical monitoring of the chemical constituents of mineral waters is a useful method for understanding the changes of geochemical environment in the Earth's crust. Recently, Takahashi et al. [38] reported a temporal change in thermal waters related to volcanic activity of Tokachidake Volcano, Japan. They observed an increase of $\mathrm{Cl}^{-}$and $\mathrm{SO}_{4}{ }^{2-}$ concentrations at the Fujiage spa, and interpreted that such fluctuations were related to volcanic activity. Many such reports for the fluctuations of chemical constituents in groundwater or well waters related to geological activity, such as earthquakes, can also be found in the literature [29,39-42].

Numerous factors such as lithology, groundwater residence time, and atmospheric and anthropogenic inputs can become a cause for change in the chemical composition of the groundwater. Therefore, relatively stable concentrations of constituent elements in groundwater may indicate that they are under a relatively equilibrium state due to long-term crustal residence time. $\mathrm{Cl}^{-}$is a useful ion as a conservative reference element to study water-rock interactions since it doesn't readily react with other chemicals and is not chemically altered as it travels along its underground flow path. $\mathrm{Cl}$ also is an ion which is difficult to dissolve via water-rock interaction. Therefore, recycling of $\mathrm{Cl}^{-}$within the aquifer system can be neglected. In addition, if the source of $\mathrm{Cl}^{-}$is rainfall, $\mathrm{Na}^{+}$and $\mathrm{Cl}^{-}$ will fall on a line known as the Seawater Dilution Line (SWDL). Nevertheless, in bedrock aquifers, chloride concentrations tend to increase according to well depth [43]. In this case, systematic increases in chloride ion concentrations in the groundwater may be interpreted as a result of chloride ion accumulation in the aquifer due to precipitation [44].

Figures 3 and 4 are variation diagrams of the chemical components of the two bottled waters during a two-year period. They show the variation of the chemical components in the BDS (Figure 3) and BSS (Figure 4) bottled waters near during the two year monitoring period. Most of the chemical component of the BSS bottled waters display relatively constant during the two years, whereas some chemical components of BDS bottled waters such as total dissolved solid (TDS), $\mathrm{Na}^{+}, \mathrm{Mg}^{2+}, \mathrm{Sr}^{2+}$, and anions display dramatic changes during the specific period from 30 August 2015 to 18 March 2016. For example, the concentration of $\mathrm{Mg}^{2+}$ and $\mathrm{Sr}^{2+}$ in the BDS bottled waters were increased during the period from 30 August 2015 to 18 March 2016. However, $\mathrm{Na}^{+}, \mathrm{Cl}^{-}$, and $\mathrm{F}^{-}$dropped in their concentration. 
BDS

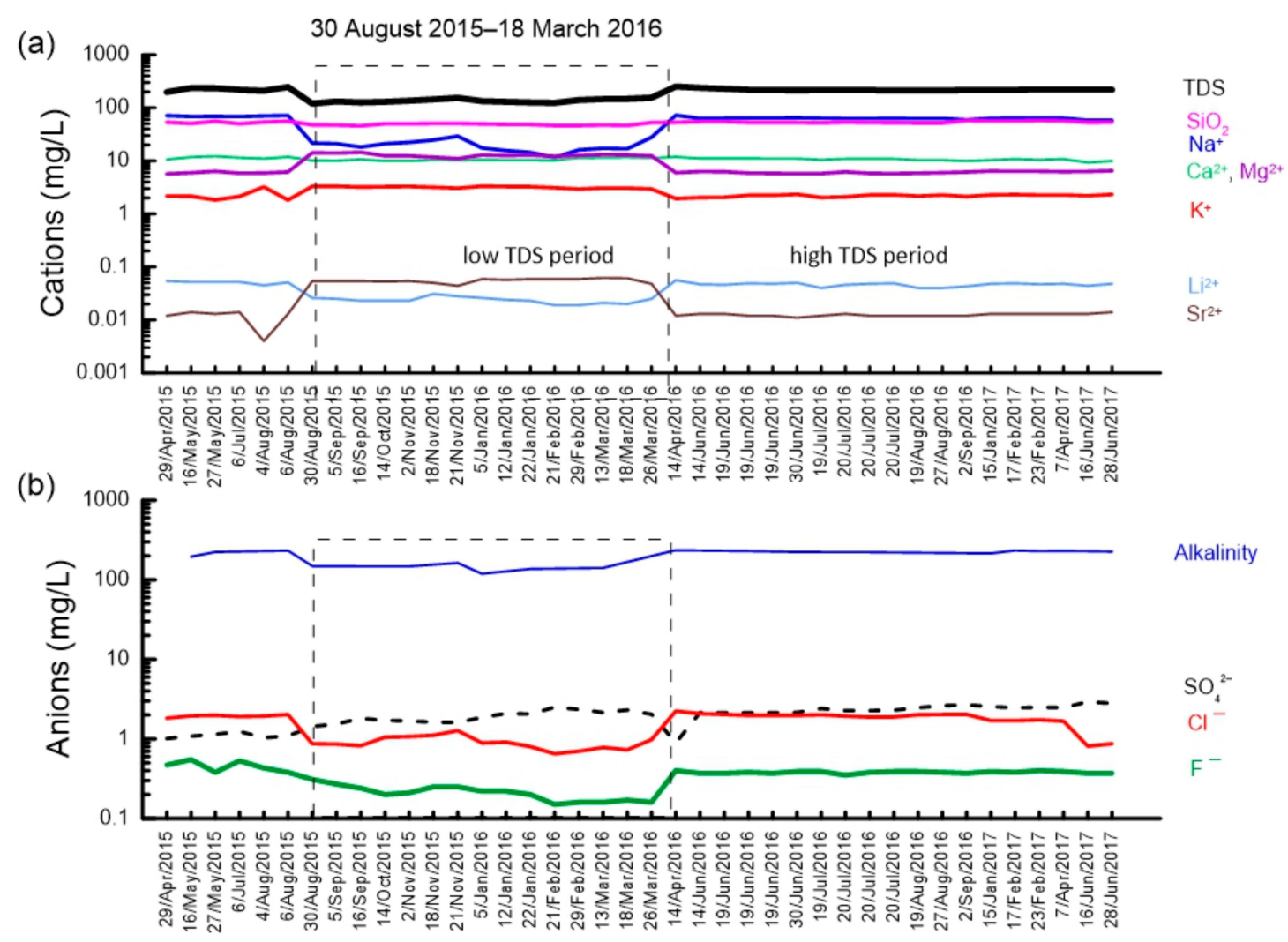

Figure 3. Variation diagram of (a) cations and (b) anions in the BDS bottled waters from April 2015 to September 2016.

(a)

\section{BSS}

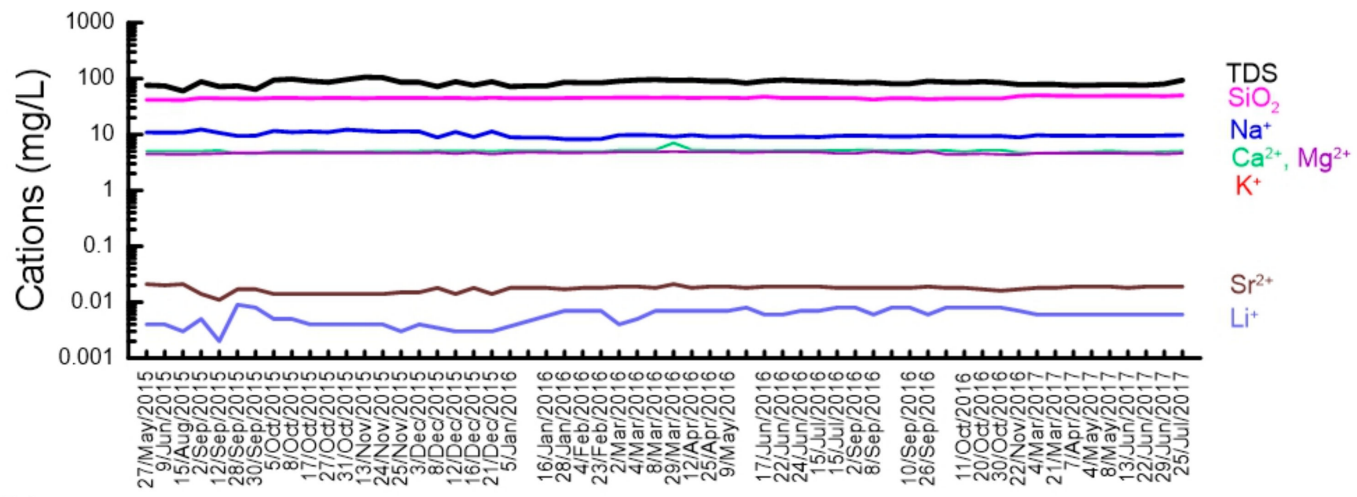

(b)

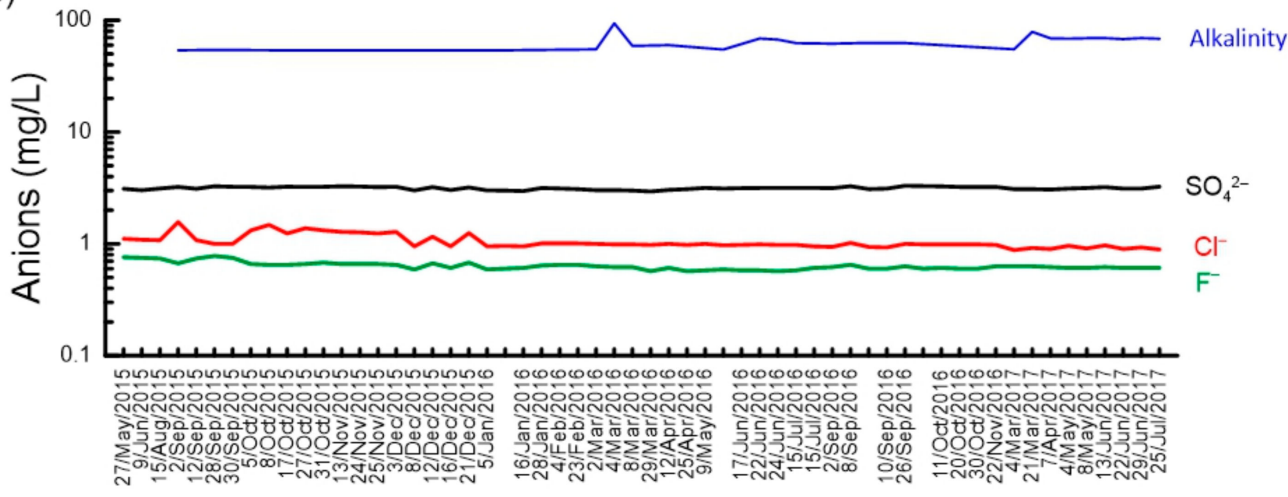

Figure 4. Variation diagram of (a) cations, and (b) anions in the BSS bottled waters from April 2015 to September 2016. 
Most of the cold spring waters around Mt. Baekdu were originated from the Cheonji (Tianchi) Lake of Mt. Baekdu. To determine the effect of hot spring waters on the BSS and BDS bottled waters, we compared the correlation between $\mathrm{Cl}^{-}$and other cations and anions (Figures 5 and 6). Cations and anions from the BSS and BDS bottled waters were plotted against $\mathrm{Cl}^{-}$in Figures 5 and 6, respectively. Figures 5 and 6 also include the data for hot and cold spring water around Mt. Baekdu (Supplementary Table S1).

$\diamond$ Hot spring water $\diamond$ Cold spring water $\bigcirc$ BDS water $\square$ BSS water

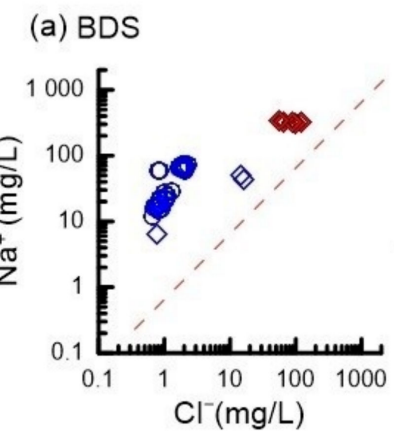

(e) BSS

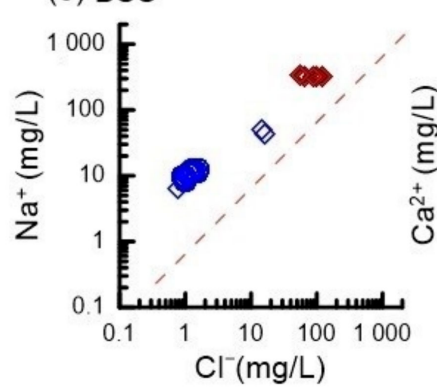

(b)

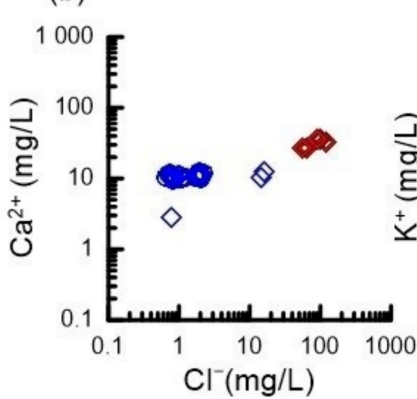

(f)

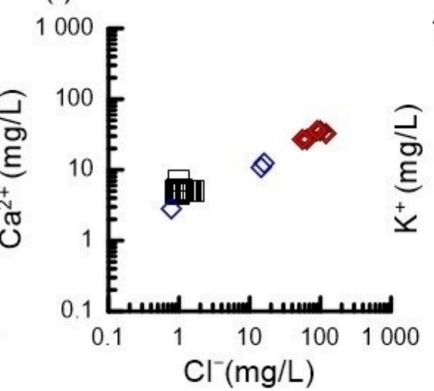

(c)

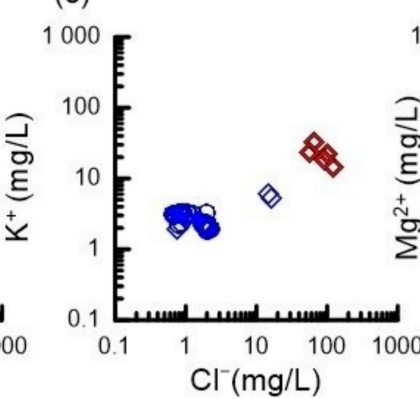

(g)

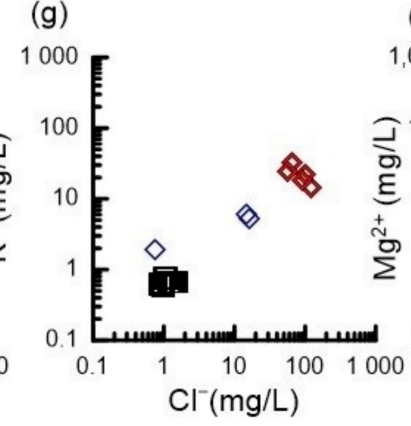

(d)

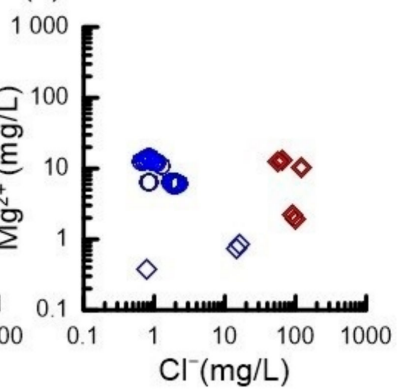

(h)

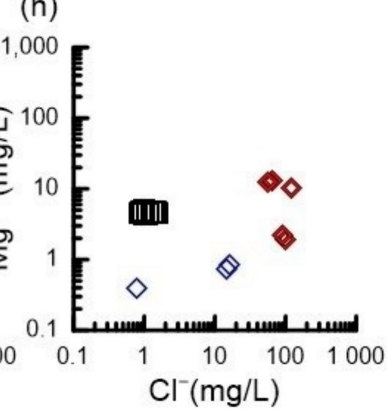

Figure 5. Relationship between $\mathrm{Cl}^{-}$and $\mathrm{Na}^{+}(\mathbf{a}, \mathbf{e}), \mathrm{Ca}^{2+}(\mathbf{b}, \mathbf{f}), \mathrm{K}^{+}(\mathbf{c}, \mathbf{g})$, and $\mathrm{Mg}^{2+}(\mathbf{d}, \mathbf{h})$ in the BDS (a-d) and BSS (eh) bottled waters, respectively. The red dotted line at (a,e) is Seawater Dilution Line (SWDL). Except for $\mathrm{Mg}^{2+}$, the chemical components of the BSS bottled waters seems to indicate that they have closer relationship with the hot spring waters in the Mt. Baekdu area.

In Figure 5, $\mathrm{Na}^{+}$ion concentrations in the bottled waters, cold and hot spring waters all plot above the sea water dilution line (SWDL) indicating $\mathrm{Na}^{+}$ion excess and water-rock interactions. Figures 5 and 6 also show that cation and anions from the hot spring and cold springs have a positive relationship with $\mathrm{Cl}^{-}$concentrations, which clearly indicates that they were released by water-rock interactions. However, $\mathrm{Na}^{+}$and $\mathrm{Ca}^{2+}$ of the BDS bottled waters seems to indicate that they are different from evolution trend of those of cold and hot spring waters. In the case of the BSS bottled waters, except for $\mathrm{Mg}^{2+}$ and $\mathrm{SO}_{4}{ }^{2-}$, most cation and anions show a good relationship with those of the cold and hot spring waters. Such different features between the two bottled waters seem to suggest that the two bottled waters in this article have different evolution trends from one other.

In Figure 3, we mentioned that chemical components of the BDS bottled waters displayed dramatic changes during the specific period from 30 August 2015 to 18 March 2016. However, Figures 5 and 6 did not show such dramatic changes due to the large difference between the chemical components of between hot spring waters and the BDS bottled waters. Therefore, we redetermined the relationship between $\mathrm{Cl}^{-}$and other ions in the BDS bottle waters, excluding the data of hot and cold spring water around Mt. Baekdu (Figure 7). Figure 7 clearly reveals that the concentration variation of cations divided into two areas compared to $\mathrm{Cl}^{-}$ion concentration, such as low $\mathrm{Cl}^{-}$and high $\mathrm{Cl}^{-}$. Particularly, the BDS bottled waters produced during low $\mathrm{Cl}^{-}$ion concentration period has a geochemical characteristic that, except $\mathrm{K}^{+}$and $\mathrm{Ca}^{2+}$, the dissolved ions have positive $\left(\mathrm{Na}^{+}, \mathrm{Li}^{+}\right.$, alkalinity) and negative $\left(\mathrm{Mg}^{2+}, \mathrm{Sr}^{2+}\right.$ and $\left.\mathrm{SO}_{4}{ }^{2-}\right)$ correlation with Cl- 
ion concentration. Furthermore, it may be possible to interpret that a strong correlation between $\mathrm{Na}^{+}$and $\mathrm{Cl}^{-}$ions in the BDS bottled waters indicates that sodium is derived from the bedrock due to water-rock interactions over a long period. The decrease in $\mathrm{Mg}^{2+}$ and $\mathrm{Sr}^{2+}$ ion concentrations may be due to precipitation of carbonate minerals [45].

$\diamond$ Hot spring water $\diamond$ Cold spring water $\bigcirc$ BDS water $\boldsymbol{\square}$ BSS water

(a) BDS

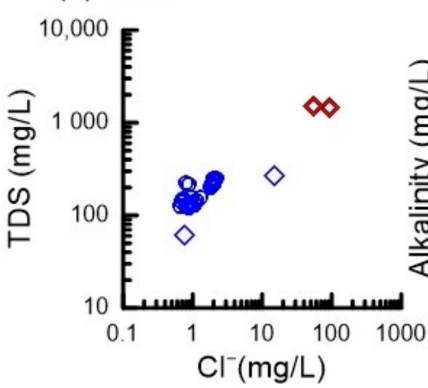

(e) BSS

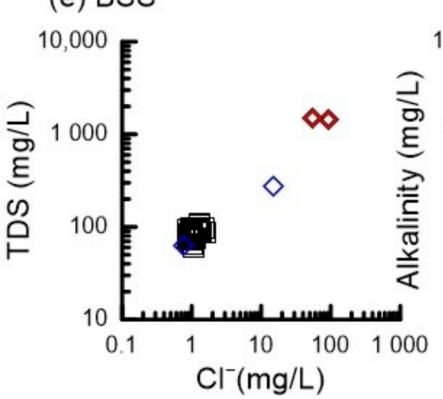

(b)

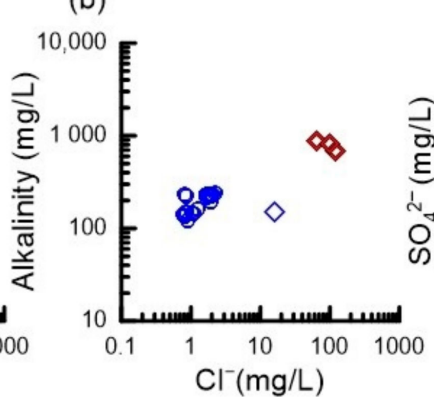

(f)

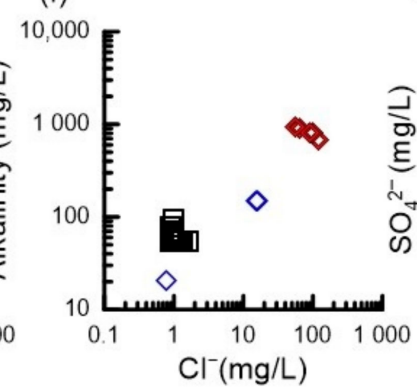

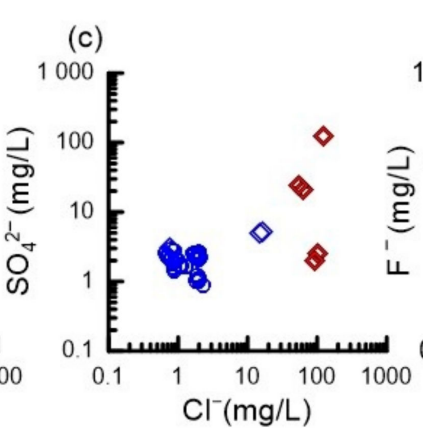

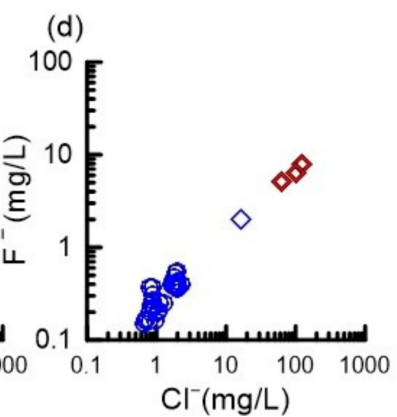

(g)

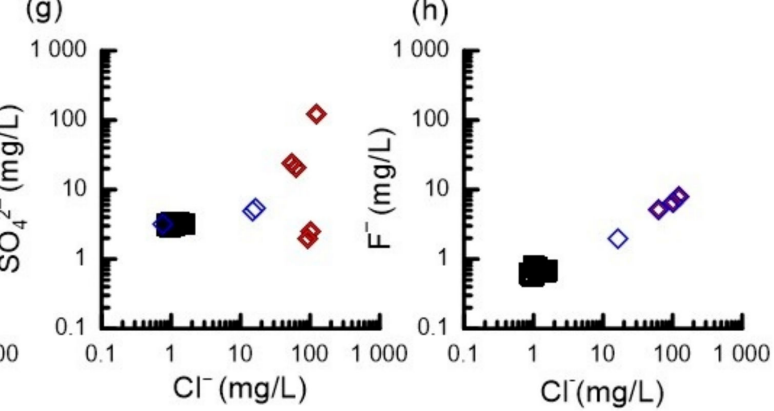

Figure 6. Relationship between $\mathrm{Cl}^{-}$and (a) and (e) total dissolved solid (TDS), (b) and (f) alkalinity, (c) and (g) $\mathrm{SO}_{4}{ }^{2-}$, and (d) and (h) $\mathrm{F}^{-}$in the BDS and BSS bottled waters, respectively.

low TDS period $\mathbf{\square}$ high TDS period

(a)

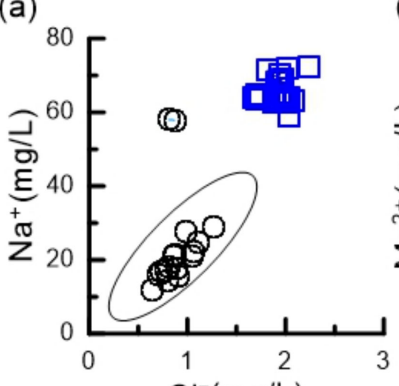

(e)

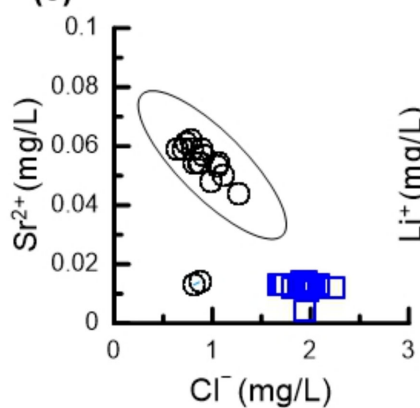

(b)

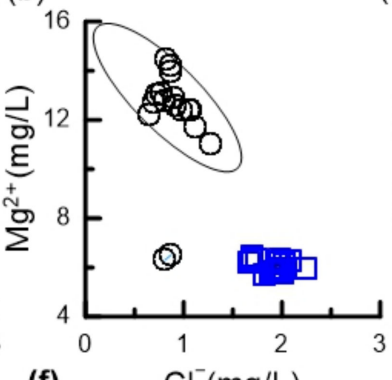

(f) (c)

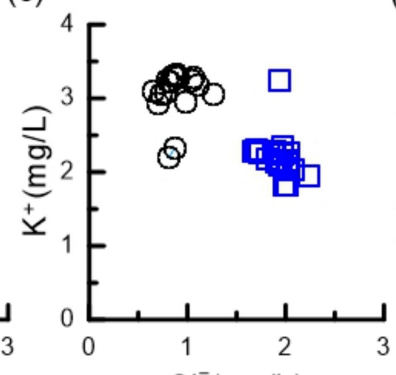

(g) $\mathrm{Cl}^{-}(\mathrm{mg} / \mathrm{L})$

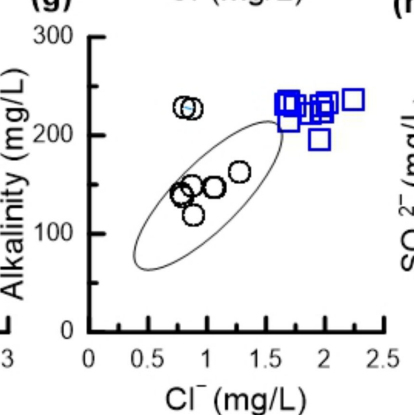

(d)

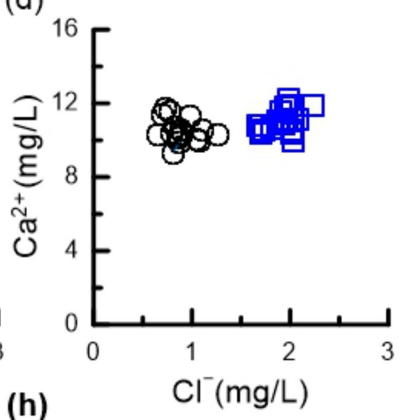

(h)

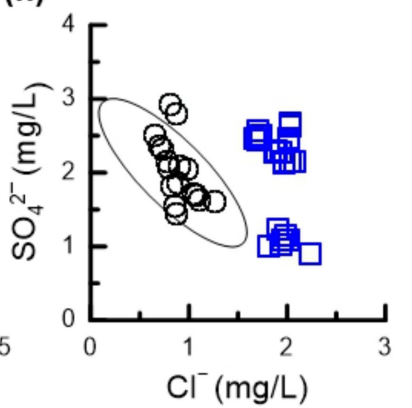

Figure 7. Relationship between chloride and (a) $\mathrm{Na}^{+},(\mathbf{b}) \mathrm{Mg}^{2+},(\mathbf{c}) \mathrm{K}^{+},(\mathbf{d}) \mathrm{Ca}^{2+}$ (e) $\mathrm{Sr}^{2+}(\mathbf{f}) \mathrm{Li}^{+}(\mathbf{g})$ alkalinity and $(\mathbf{h}) \mathrm{SO}_{4}{ }^{2-}$ ion in the BDS bottled waters. 
Therefore, in Figure 7, the relationship between cations and $\mathrm{Cl}^{-}$may be interpreted to the extent that the systematic variation in $\mathrm{Li}^{+}, \mathrm{Na}^{+}$, and $\mathrm{Mg}^{2+}$ ion concentrations against $\mathrm{Cl}^{-}$concentrations in the BDS bottled waters does not necessarily relate to volcanic activity in the Mt. Baekdu area.

\subsection{Isotope Geochemistry of the Bottled Waters}

The groundwater with isotopic data of $\delta^{18} \mathrm{O}$ and $\delta \mathrm{D}$ falling on the meteoric water line can be assumed to have originated form condensation of water vapor and to be unaffected by other isotopic processes. Therefore, it can be concluded that concentrations of chloride ions from both bottled waters are essentially meteoric in origin.

In Figure 2b, BDS derived from the bedrock aquifer showed that they are meteoric in origin. However, BSS produced from the artesian well showed a geochemical characteristic that may be a result of $\mathrm{CO}_{2}$ exchange via water-rock interaction. The relationship between $\mathrm{Cl}^{-}, \delta^{18} \mathrm{O}$, and $\delta \mathrm{D}$ also reveals that BSS and BDS bottled waters have different water-rock interactions (Figure 8).

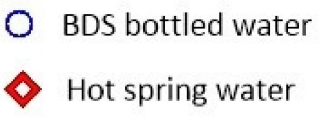

- BDS bottled water

Hot spring water
BSS bottled water

Spring water near to hot spring water
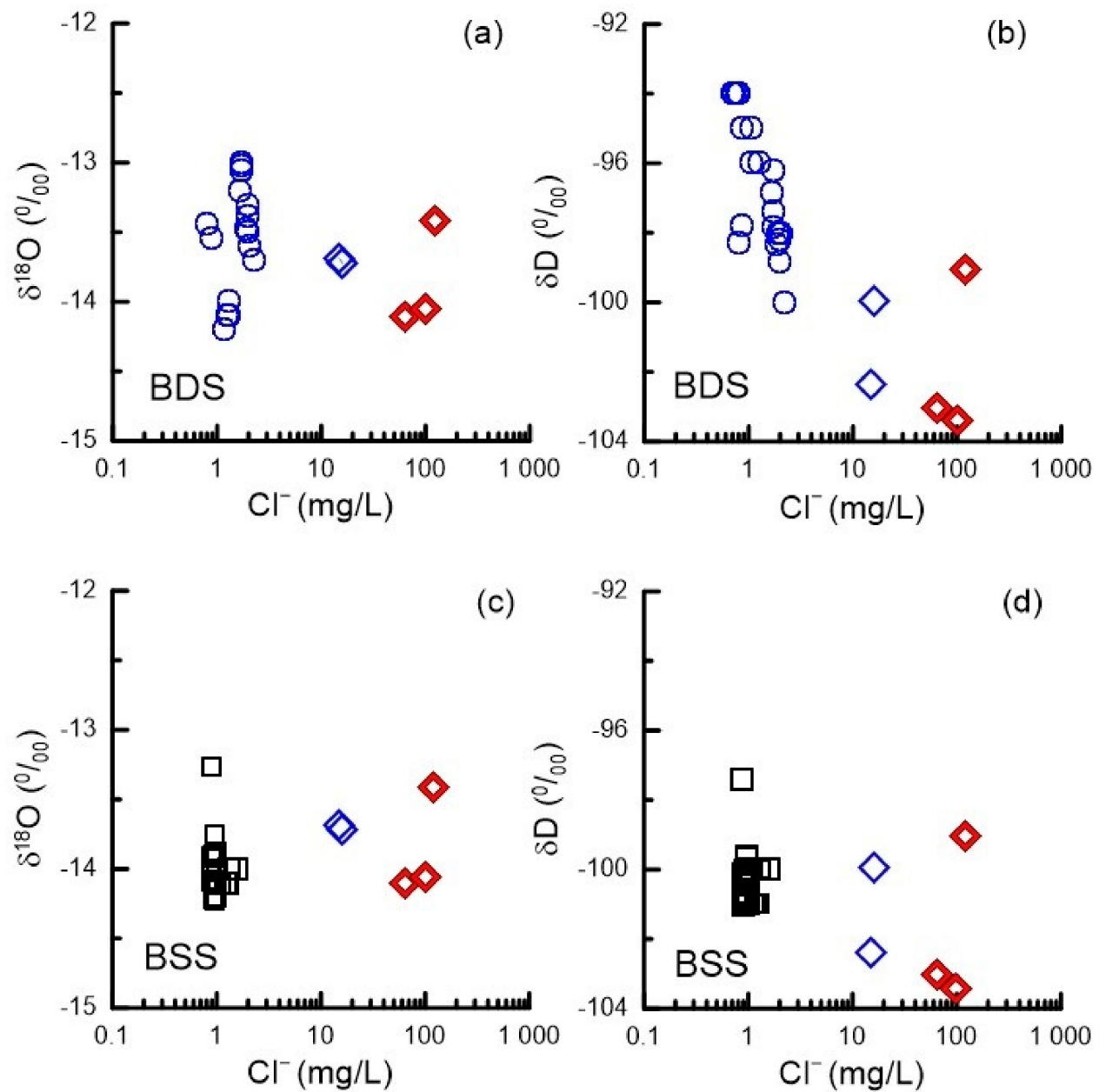

Figure 8. Relationship between chloride and $\delta^{18} \mathrm{O}$, and $\delta \mathrm{D}$ in two bottled waters, hot spring and cold spring waters. $(\mathbf{a}, \mathbf{b})$ are from BDS bottled waters, and $(\mathbf{c}, \mathbf{d})$ are from BSS bottled waters.

${ }^{87} \mathrm{Sr} /{ }^{86} \mathrm{Sr}$ vs. $1 / \mathrm{Sr}$ diagram also indicates that BDS bottled waters was produced from two kinds of aquifers (Figure 9). Lee et al. [46] showed that chemical components 
in solution gradually increase during water-rock interaction experiments of one year, suggesting that the chemical composition of groundwater does not equilibrate during short periods. Therefore, it could be interpreted that the abrupt change in concentrations of chemical constituents in the BDS bottled waters may be derived from different aquifers during the monitoring period, suggesting that the different geochemical characteristics of the BDS bottled waters seem to be related to changes in the pumping wells (i.e., possible change of aquifer and lithology).

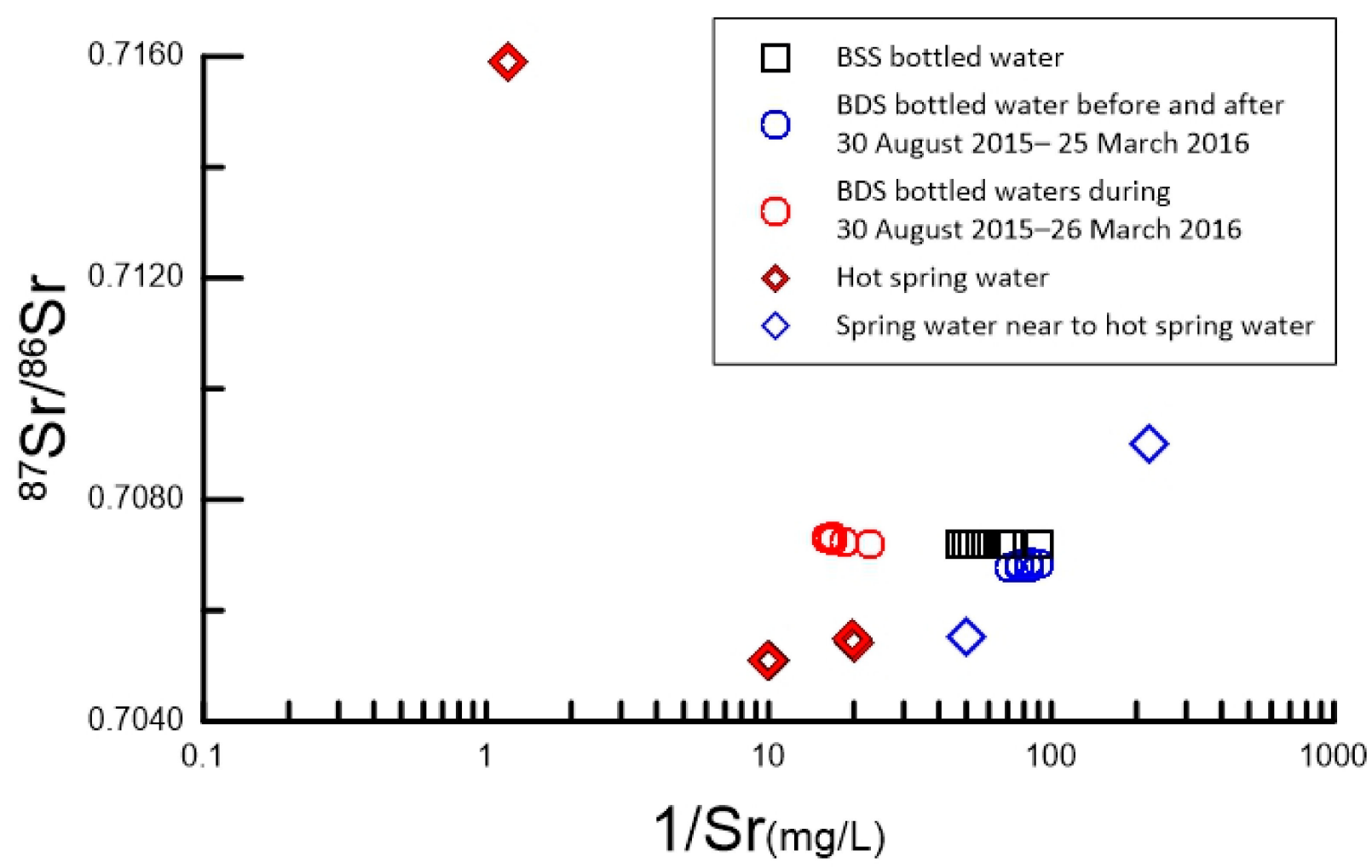

Figure 9. ${ }^{87} \mathrm{Sr} /{ }^{86} \mathrm{Sr}$ ratios vs $1 / \mathrm{Sr}$ concentrations $(\mathrm{mg} / \mathrm{L})$ of the bottled waters in the Mt. Baekdu area from April 2015 to September 2016. The ${ }^{87} \mathrm{Sr} /{ }^{86} \mathrm{Sr}$ ratios of the BDS bottled waters (red circles) from 30 August 2015 to 26 March 2016 are higher than those (blue circles) of before and after the period. However, the BSS bottled waters (rectangles) have almost same values in ${ }^{87} \mathrm{Sr} /{ }^{86} \mathrm{Sr}$ ratios. The data of hot spring waters and cold spring waters were used from this study (Table S1) and Han and Huh [7].

At present, due to a lack of information on the two bottled waters, it may be difficult to define a water-rock interaction in the aquifer which could produce the two bottled waters. Nevertheless, the geochemical characteristics seem to indicate that the BSS bottled waters might be produced by simple water-rock interactions from one aquifer whereas the BDS bottled waters seems to be produced by pumping from mixed aquifers.

\section{Summary and Conclusions}

Two commercial bottled waters (BSS and BDS) from the Mt. Baekdu area were collected from April 2015 to September 2016 in order to investigate the possible usefulness of chemical composition variation of the bottled waters in monitoring nearby volcanic activity.

The BSS bottled waters produced from the northern part of Mt. Baekdu reveal a linear variation in chemical composition against $\mathrm{Cl}^{-}$, whereas the BDS bottled waters produced from the southern part of Mt. Baekdu show abrupt changes in its chemical composition. The change in chemical composition of the BDS bottled waters seems to be due to pumping the aquifer at different depths, whereas the variation in chemical components against $\mathrm{Cl}$ from the BSS bottle water seems to be due to water-rock interactions in the aquifer with bedrock of various kinds of mineral composition. 
Our results suggest that monitoring of bottle water sourced near the volcanic area may be useful in understanding the cause of the variation in chemical compositions of the groundwater due to water-rock interactions.

Supplementary Materials: The following are available online at https://www.mdpi.com/article/ 10.3390/w13162191/s1. Table S1: Chemical composition of the hot and cold spring water at the Mt. Baekdu area; Table S2: Chemical composition of the BDS bottled waters; Table S3: Chemical composition of the BSS bottled waters.

Author Contributions: Original concept and writing the paper, S.-G.L. and D.-C.K.; hot-spring water sampling at Mt. Baekdu, K.H., Y.S.L., Z.C., and S.-S.C.; the measurement of bi-carbonate concentration, Y.-Y.J.; project design, K.-S.K. and Y.S.L. All authors have read and agreed to the published version of the manuscript.

Funding: This research was supported by the National Research Council of Science and Technology (NST) grant by the Korean government (MSIP) (CAP-17-05-KIGAM, K.S. Ko) and the Principal Research Fund of the Korea Institute of Geoscience and Mineral Resources (GP2014-022, Y.S. Lee).

Acknowledgments: We thank two anonymous reviewers for their help in improving the manuscript.

Conflicts of Interest: The authors declare no conflict of interest.

\section{References}

1. Stone, R. Is China's Riskiest Volcano Stirring or Merely Biding Its Time? Science 2010, 329, 498-499. [CrossRef]

2. Stone, R. Vigil at North Korea's Mount Doom. Science 2011, 334, 584-588. [CrossRef]

3. Xu, J.; Liu, G.; Wu, J.; Ming, Y.; Wang, Q.; Cui, D.; Shangguan, Z.; Pan, B.; Lin, X.; Liu, J. Recent unrest of Changbaishan volcano, northeast China: A precursor of a future eruption? Geophys. Res. Lett. 2012, 39, L16305. [CrossRef]

4. Wei, H.; Liu, G.; Gill, J. Review of eruptive activity at Tianchi volcano, Changbaishan, northeast China: Implications for possible future eruptions. Bull. Volcanol. 2013, 75, 706. [CrossRef]

5. Shangguan, Z.; Zheng, Y.; Dong, J. Material sources of escaped gases from Tianchi volcanic geothermal area, Changbai Mountains. Sci. China Ser. D Earth Sci. 1997, 40, 390-397. [CrossRef]

6. Hahm, D.; Hilton, D.R.; Cho, M.; Wei, H.; Kim, K.-R. Geothermal He and $\mathrm{CO}_{2}$ variations at Changbaishan intra-plate volcano (NE China) and the nature of the sub-continental lithospheric mantle. Geophys. Res. Lett. 2008, 35. [CrossRef]

7. Han, Y.; Huh, Y. A geochemical reconnaissance of the Duman (Tumen) River and the hot springs of Mt. Baekdu (Changbai): Weathering of volcanic rocks in mid-latitude setting. Chem. Geol. 2009, 264, 162-172. [CrossRef]

8. Yan, B.; Xiao, C.; Liang, X.; Wei, R.; Wu, S. Characteristics and genesis of mineral water from Changbai Mountain, Northeast China. Environ. Earth Sci. 2014, 73, 4819-4829. [CrossRef]

9. Yan, B.; Qiu, S.; Liu, Z.; ChangLai, X. Characteristics of the geothermal water in Changbai Mountain volcanic region, northeast of China. Arab. J. Geosci. 2017, 10, 261. [CrossRef]

10. Yan, B.; Liang, X.; Xiao, C. Hydrogeochemical Characteristics and Genesis Model of Jinjiang and Julong Hot Springs in Changbai Mountain, Northeast China. Geofluids 2018, 2018, 1694567. [CrossRef]

11. Bong, Y.-S.; Ryu, J.-S.; Lee, K.-S. Characterizing the origins of bottled water on the South Korean market using chemical and isotopic compositions. Anal. Chim. Acta 2009, 631, 189-195. [CrossRef]

12. Birke, M.; Rauch, U.; Harazim, B.; Lorenz, H.; Glatte, W. Major and trace elements in German bottled water, their regional distribution, and accordance with national and international standards. J. Geochem. Explor. 2010, 107, 245-271. [CrossRef]

13. Bityukova, L.; Petersell, V. Chemical composition of bottled mineral waters in Estonia. J. Geochem. Explor. 2010, 107, $238-244$. [CrossRef]

14. Brenčič, M.; Ferjan, T.; Gosar, M. Geochemical survey of Slovenian bottled waters. J. Geochem. Explor. 2010, 107, 400-409. [CrossRef]

15. Cicchella, D.; Albanese, S.; De Vivo, B.; Dinelli, E.; Giaccio, L.; Lima, A.; Valera, P. Trace elements and ions in Italian bottled mineral waters: Identification of anomalous values and human health related effects. J. Geochem. Explor. 2010, 107, 336-349. [CrossRef]

16. Demetriades, A. General ground water geochemistry of Hellas using bottled water samples. J. Geochem. Explor. 2010, 107, 283-298. [CrossRef]

17. Dinelli, E.; Lima, A.; De Vivo, B.; Albanese, S.; Cicchella, D.; Valera, P. Hydrogeochemical analysis on Italian bottled mineral waters: Effects of geology. J. Geochem. Explor. 2010, 107, 317-335. [CrossRef]

18. Dotsika, E.; Poutoukis, D.; Raco, B.; Psomiadis, D. Stable isotope composition of Hellenic bottled waters. J. Geochem. Explor. 2010, $107,299-304$.

19. Fugedi, U.; Kuti, L.; Jordan, G.; Kerek, B. Investigation of the hydrogeochemistry of some bottled mineral waters in Hungary. J. Geochem. Explor. 2010, 107, 305-316. [CrossRef] 
20. Frengstad, B.S.; Lax, K.; Tarvainen, T.; Jæger, Ø.; Wigum, B.J. The chemistry of bottled mineral and spring waters from Norway, Sweden, Finland and Iceland. J. Geochem. Explor. 2010, 107, 350-361. [CrossRef]

21. Smedley, P.L. A survey of the inorganic chemistry of bottled mineral waters from the British Isles. Appl. Geochem. 2010, 25, 1872-1888. [CrossRef]

22. Kermanshahi, K.Y.; Tabaraki, R.; Karimi, H.; Nikorazm, M.; Abbasi, S. Classification of Iranian bottled waters as indicated by manufacturer's labellings. Food Chem. 2010, 120, 1218-1223. [CrossRef]

23. Peh, Z.; Šorša, A.; Halamić, J. Composition and variation of major and trace elements in Croatian bottled waters. J. Geochem. Explor. 2010, 107, 227-237. [CrossRef]

24. Kim, G.-E.; Shin, W.-J.; Ryu, J.-S.; Choi, M.-S.; Lee, K.-S. Identification of the origin and water type of various Korean bottled waters using strontium isotopes. J. Geochem. Explor. 2013, 132, 1-5. [CrossRef]

25. Raco, B.; Dotsika, E.; Feroni, A.C.; Battaglini, R.; Poutoukis, D. Stable isotope composition of Italian bottled waters. J. Geochem. Explor. 2013, 124, 203-211. [CrossRef]

26. Astel, A.; Michalski, R.; Łyko, A.; Jabłońska-Czapla, M.; Bigus, K.; Szopa, S.; Kwiecińska, A. Characterization of bottled mineral waters marketed in Poland using hierarchical cluster analysis. J. Geochem. Explor. 2014, 143, 136-145. [CrossRef]

27. Edmunds, W.; Carrillo-Rivera, J.; Cardona, A. Geochemical evolution of groundwater beneath Mexico City. J. Hydrol. 2002, 258, 1-24. [CrossRef]

28. Locsey, K.L.; Grigorescu, M.; Cox, M.E. Water-Rock Interactions: An Investigation of the Relationships Between Mineralogy and Groundwater Composition and Flow in a Subtropical Basalt Aquifer. Aquat. Geochem. 2011, 18, 45-75. [CrossRef]

29. Tsunogai, U.; Wakita, H. Precursory chemical changes in groundwater: Kobe Earthquake, Japan. Science 1995, 269, 61-63. [CrossRef]

30. Tsunogai, U.; Wakita, H. Anomalous changes in groundwater chemistry: Possible precursors of the $1995 \mathrm{Hyogo}-\mathrm{ken}$ Nambu earthquake, Japan. J. Phys. Earth 1996, 44, 381-390. [CrossRef]

31. Brand, W.A.; Geilmann, H.; Crosson, E.R.; Rella, C.W. Cavity ring-down spectroscopy versus high-temperature conversion isotope ratio mass spectrometry; a case study on $\delta^{2} \mathrm{H}$ and $\delta^{18} \mathrm{O}$ of pure water samples and alcohol/water mixtures. Rapid Commun. Mass Spectrom. 2009, 23, 1879-1884. [CrossRef]

32. Jung, Y.-Y.; Koh, D.-C.; Lee, J.; Ko, K.-S. Applications of Isotope Ratio Infrared Spectroscopy (IRIS) to Analysis of Stable Isotopic Compositions of Liquid Water. Econ. Environ. Geol. 2013, 46, 495-508. [CrossRef]

33. Craig, H. Isotopic Variations in Meteoric Waters. Science 1961, 133, 1702-1703. [CrossRef]

34. Chen, Z.; Wei, W.; Liu, J.; Wang, Y.; Chen, J. Identifying the recharge sources and age of groundwater in the Songnen Plain (Northeast China) using environmental isotopes. Hydrogeol. J. 2011, 19, 163-176. [CrossRef]

35. Schwartz, F.W.; Zhang, H. Fundamentals of Groundwater; John Wiley \& Sons: New York, NY, USA, 2003; Volume 583, 592p.

36. Siegenthaler, U.; Oeschger, H. Correlation of ${ }^{18} \mathrm{O}$ in precipitation with temperature and altitude. Nat. Cell Biol. 1980, $285,314-317$. [CrossRef]

37. Poage, M.; Chamberlain, C.P. Empirical relationships between elevation and the stable isotope composition of precipitation and surface waters: Considerations for studies of Paleoelevation change. Am. J. Sci. 2001, 301, 1-15. [CrossRef]

38. Takahashi, R.; Shibata, T.; Maruyama, Y.; Ogino, T.; Okazakai, N. Temporal changes in thermal waters related to volcanic activity of Tokachitake Volcano, Japan: Implications for forecasting future eruptions. Bull. Volcano. 2015, 77, 2. [CrossRef]

39. Hammond, D.E.; Haraguchi, G.; Teng, T.L.; Miller, L. A search for Co-variance among seismicity, groundwater chemistry, and groundwater radon in southern California. Geophys. Res. Lett. 1981, 8, 445-448. [CrossRef]

40. King, C.-Y.; Evans, W.C.; Presser, T.; Husk, R.H. Anomalous chemical changes in well waters and possible relation to earthquakes. Geophys. Res. Lett. 1981, 8, 425-428. [CrossRef]

41. Koizumi, N.; Yoshioka, R.; Kishimoto, Y. Earthquake prediction by means of change of chemical composition in mineral spring water. Geophys. Res. Lett. 1985, 12, 510-513. [CrossRef]

42. Skelton, A.; Andrén, M.; Kristmannsdóttir, H.; Stockmann, G.; Mörth, C.-M.; Sveinbjörnsdóttir, A.; Jonsson, S.; Sturkell, E.; Guðrúnardóttir, H.R.; Hjartarson, H.; et al. Changes in groundwater chemistry before two consecutive earthquakes in Iceland. Nat. Geosci. 2014, 7, 752-756. [CrossRef]

43. Kelly, W.R.; Panno, S.V.; Hackley, K.C. The Sources, Distribution, and Trends of Chloride in the Waters of Illinois; B-74; Illinois State Water Survey: Champaign, IL, USA, 2012; p. 59.

44. Aishlin, P.S. Groundwater Recharge Estimation Using Chloride Mass Balance, Dry Creek Experimental Watershed. Master's Thesis, Boise State University, Boise, ID, USA, December 2006; p. 622.

45. Dogramaci, S.S.; Herczeg, A.L.; Bone, Y. Sr in groundwater as indicators of carbonate dissolution. Water-Rock Inter. 1998, WRI-9, 211-214. [CrossRef]

46. Lee, S.-G.; Kim, J.C. Preliminary experimental result for clarifying Sr Isotope behaviour of water due to water-rock interaction. Econ. Environ. Geol. 2010, 53, 211-222, with English Abstract. 